\title{
Individen och samhället i Claes Anderssons 1960- och 1970-talspoesi
}

Claes Andersson har varit en radikal förnyare av den finlandssvenska poesin både vad gäller ämnen och formella grepp, inte minst har han öppnat upp genren för samtidens sociala frågor. Artikeln behandlar förhållandet mellan individen och samhället i Anderssons 1960- och 1970-talspoesi. Ett urval dikter analyseras i sin vänsterideologiska samtidskontext och i relation till tidens aktuella teorier inom sociologi, marxism och psykiatri.Tre tematiska aspekter strukturerar framställningen: solidaritet, urban anonymitet och psykiatrins roll.

\section{Inledning}

"Sköt dig själv och skit i andra" - i det finländska samhället år 2000 har den råa kapitalismens inställning enligt Claes Andersson blivit allt vanligare och attityderna hårdnat. Effektivitet, vinstmaximering och konsumtionsfest dominerar på bekostnad av mellanmänsklig omtanke och solidaritet. Det finns en ovilja att delta i finansieringen av de offentliga tjänsterna kring skola, omsorg och vård. Margaret Thatchers berömda uttalande "egentligen finns det ingenting sådant som ett samhälle" verkar ha börjat gro hos de radikalaste på högerkanten. (Andersson 2000: 173.) Anderssons bedömning av läget kring millennieskiftet (och utvecklingen har sedan dess fortsatt i en nyliberalistisk riktning) följer upp samhällskritiken och vänsterideologin från hans ungdomstid. På 1960och 1970-talen delades ett sådant antikapitalistiskt synsätt av många, till exempel av den numera nyliberalistiske Björn Wahlroos (Berggren \& Lydén 2009: 26, 53). Det var överhuvudtaget en tid av samhällskritiska ideologiska strömningar i hela västvärlden; marxismen, feminismen och miljörörelsen ville på olika sätt förändra skeva maktstrukturer och verka för större rättvisa, jämlikhet och gemensamt ansvarstagande. En del tänkte också att världen kunde bli bättre med hjälp av poesi. Claes Andersson hörde till dem.

I den finlandssvenska poesin innebar sextio- och sjuttiotalen en brytningsfas då en ny diktargeneration gjorde upp med en dominerande centrallyrisk och naturinspirerad modernistisk tradition. Litterära impulser kom för Anderssons del bland annat från de amerikanska beatpoeterna Allen Ginsberg och Lawrence Ferlinghetti men också från den nyaste rikssvenska och finska poesin bland annat i form av konkretism, nyenkelhet och collageteknik (Andersson 2006: 90-93). Vesa Haapala påpekar att i jämförelse med 1920-talet är 1960-talets litteraturhistoriska situation i Finland omsvängd: medan den finska litteraturen tidigare fått sin experimentella inspiration från den finlandssvenska modernismen kom de avantgardistiska impulserna på 1960-talet in i finlandssvensk litteratur via den finska litteraturen (Haapala 2007: 292). Haapala betraktar också sextiotalets experimentella finländska litteratur som en uppö̈ljning av den tidiga modernismens program i västerländsk litteratur kring 
sekelskiftet, och visar hur det som skedde i 1950-talets finska modernism banade väg för följande decenniums ideologiska poetik (Haapala 2007: 280-284). Men i den finlandssvenska poesin hade modernismen redan långt tidigare förlorat sin avantgardistiska prägel.

Andersson var initiativtagare till och huvudredaktör för den radikala kulturtidskriften FBT (en nonsensaktig bokstavskombination utan innebörd), som utgavs under åren 1965-68. Bland punkterna i tidskriftens manifest fanns åsikten att kulturpolitik och samhällspolitik var två sidor av samma sak och att människan måste vara huvudsaken, att kultur inte är något "fint" utan hör hemma i vardagen och verkligheten, att alla gränsdragningar (språkliga, politiska, etniska, nationella) bör ifrågasättas, att kulturklimatet ska innehålla fri debatt om brännbara frågor, att litteraturen måste förändras och utvecklas - och att den finlandssvenska modernismen var död. (Rönnholm 1986: 266.) I mitten av 60-talet var Andersson med och grundade Socialdemokratiska Studentföreningen, vilket var en radikal åtgärd på den tiden, och mot slutet av decenniet deltog han aktivt i Novemberrörelsen och blev också dess ordförande (Andersson 2000: 97, 20). Målet för denna rörelse, som verkade i Finland under 1960-talets senare hälft, var en humanare fångvård, bättre rättsskydd för mentalpatienter, stöd för bostadslösa alkoholister och ökad tolerans mot etniska och sexuella minoriteter (Andersson 2000: 18I). Som psykiater kom Andersson i närkontakt med de utslagna och hjälpbehövande i samhället. Dessa konkreta erfarenheter från det finländska samhället kunde han använda i sina dikter för att synliggöra, kritiskt granska, ifrågasätta och försöka förändra missförhållanden.

"Vill man gå upp det radikala samvetets historia i Finland under det senaste kvartsseklet är få lyriska insatser lika brukbara vägvisare som Claes Anderssons", skriver Clas Zilliacus (1986: I5I). Men trots att Andersson hör till de kändaste poeterna i Finland och hans lyrik så väl belyser ett ideologiskt-historiskt skede, är hans författarskap föga utforskat. Jag finner det därför motiverat att här ta tag i ett centralt och representativt drag hos Andersson, nämligen frågan om förhållandet mellan individen och samhället sådant det framställs i hans 1960-1970-talspoesi. Naturligtvis har detta berörts tidigare i recensioner, artiklar (t.ex. Laihinen 197I; Zilliacus 1972; Wrede 1980) och efterord (se Ekman 2012), men det har inte undersökts som en särskild fråga. Den kvantitativt sett ringa forskning som finns är också huvudsakligen från 1970- och 80-talen, från en tid som sammanföll med eller stod de ifrågavarande decennierna mentalitetsmässigt nära, och jag tror att det fjärmande tidsavståndet idag kan synliggöra sådant som tedde sig mera självklart då. Mitt syfte är mera specifikt att undersöka hur Andersson hanterar nya ämnen i finlandssvensk poesi såsom solidaritet, (efterkrigstida) urban anonymitet och psykiatrins roll - dessa är delaspekterna som artikeln struktureras kring - och på vilket sätt han som poet är delaktig i en samtida offentlig diskussion inom marxism, antipsykiatri och sociologi. Närmelsesättet är tematiskt och idéhistoriskt. Exempel hämtas ur följande diktsamlingar: Samhället vi dör i (1967), Det är inte lätt att vara villaägare i dessa tider (1969), Bli, tillsammans (1970), Rumskamrater (1974), Genom sprickorna i vårt ansikte (1977) och Trädens sånger (1979). 


\section{Solidaritet: något som händer oss}

I diktsamlingen med den ironiska titeln Det är inte lätt att vara villaägare $i$ dessa tider (imiterande "borgarens" föreställning om sina förmenta ekonomiska bekymmer) finns följande dikt, som är politisk men samtidigt problematiserar det politiska engagemanget:

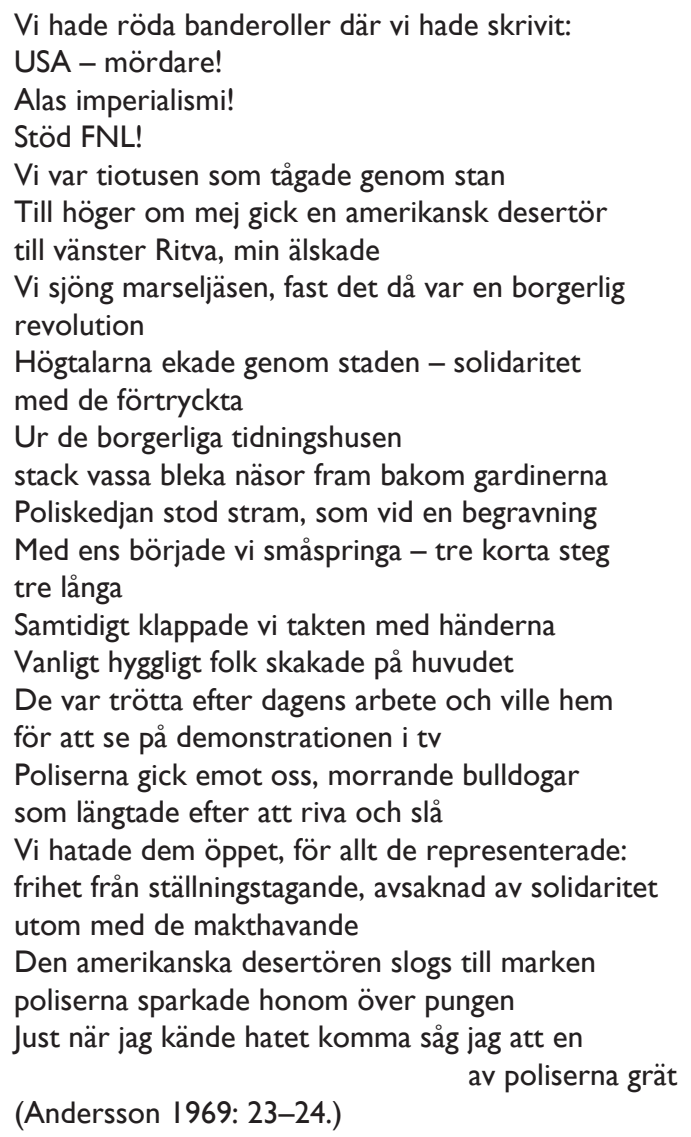

FNL är en förkortning av Sydvietnams nationella befrielsefront (på franska Front National de Libération du Viêt-nam du Sud), en ledande gerillarörelse som dominerades av kommunister. Den grundades 1960 för att bekämpa den sydvietnamesiske presidenten Ngô Dinh Diêms regim och befria Sydvietnam från USA-imperialismen.' Fördömandet av USA:s krigföring i Vietnam var vid sidan av kritiken mot det kapitalistiska systemet något som förenade den annars i flera avseenden disparata vänstervågen. Motivet engagerade också poeter. Göran Sonnevis dikt "Om kriget i Vietnam" från 1965 fick omedelbart genomslag, debatterades och blev något av ett portalverk för den svenska Vietnamrörelsen. Dikten kom att fungera som en modell för hur den effektiva politiska dikten skulle se ut: den utgick från den vanlige svenskens upplevelse, från nyhetsrapporteringen om omskakande händelser på andra sidan jordklotet som via tv:n kom in i vardagsrummet. (Svedjedal 20l4: 58-59.) Stilen i Sonnevis dikt är återhållen, saklig och beskrivande och informationen från tv:ns rapportering om krigsnöden i Vietnam vävs samman

\footnotetext{
Nationalencyklopedin, "FNL", http://www.ne.se/uppslagsverk/encyklopedi/lång/fnl (hämtat 6.2.20I5).
} 
med snöfallet i Lund, där knappast någon dör "av annat än personliga skäl" (Sonnevi 1985: 739). När Claes Andersson i sin dikt beskriver ett finländskt demonstrationståg mot USA:s behandling av Vietnam tar han ställning till en aktuell politisk fråga och knyter an till den politiska samtidsdiktens motiv och stilmedel.

I Anderssons dikt gestaltas den kollektiva upplevelsen, delaktigheten $\mathrm{i}$ vänstervågens nations- och språköverskridande gemenskap men samtidigt anläggs ett yttre, analytiskt perspektiv på detta vi. Tempusformen i imperfekt ger också ett intryck av reflexivt avstånd. Sättet att framställa demonstranternas uppfattning om poliserna - "Vi hatade dem öppet, för allt de representerade: / frihet från ställningstagande, avsaknad av solidaritet / utom med de makthavande" - låter som en imitation av gruppens eget språkbruk och av en indoktrinerad attityd, vilket inte minst kolonet bidrar till. Noteringen att "vanligt hyggligt folk" var trötta och ville hem för att se på demonstrationen i tv är lätt ironisk men mera inkännande än avståndstagande och visar på diktjagets medvetenhet om hur händelserna tedde sig ur en annan kategoris synvinkel. Den synvinkeln måtte ha varit bekant från Anderssons barndomshem (en biografisk koppling kan göras här), där man enligt honom själv sällan talade politik. Därmed inte sagt att det saknades starka ideologiska spänningar i familjen. Pappan, som var präglad av sina krigserfarenheter, var svårt provocerad av sonens socialistiska verksamhet, bland annat hans deltagande i en Vietnamdemonstration på 1960-talet, där han också höll ett tal. (Andersson 2000: 98-99.) ${ }^{2}$ Diktens vändpunkt kommer allra sist när kollektivet och vi - de-konstellationen träder tillbaka för den enskilda individen. Den subjektiva reaktionen bryter mönstret: en polis gråter över våldet, (även) sin egen poliskårs våld. Radindraget och överklivningen markerar betydelsefullheten och för in ett mera accentuerat lyriskt element i den i övrigt förhållandevis prosaaktiga och narrativa dikten. Det blir också en signifikativ formell avvikelse som svarar mot diktens gestaltning av att gå i ledet, till och med i takt; den sista raden blir en utbrytning, en akt av individualism även om solidaritetstanken inte ges upp. Solidaritetens egentliga innebörd förmedlas med lyriktraditionens etablerade medel, men samtidigt som frasbrott och typografi ger uttryck för det hejdade och osägbara finns en stor tydlighet i den implicita sensmoralen att solidaritet måste vara något som äger rum mellan enskilda människor. Slagord, banderoller, revolutionär sång och principer kan missa det väsentliga.

2 I Berggren \& Lydéns intervjubok om unga kommunister i 1970-talets Svenskfinland, Nyttiga idioter, beskrivs vänsterupproret också som ett generationsuppror mot fäder präglade av krigserfarenheter och fosterländska ideal. En av de intervjuade säger i sin tillbakablick på det politiska engagemanget t.ex.: "Min pappa hade gått ut i vinterkriget som frivillig adertonåring. Vår uppgift som generation var att vara tacksam. Man skulle vara tacksam för att vi var fria, man skulle vara tacksam för det ena och det andra. Som ung blev man ju rabiat på det." (Berggren \& Lydén 2009: 44.) Jfr Saarikoski, som i en dikt ur Katselen Stalinin pään yli ulos skriver: "Meille sanotaan että meidän pitäisi olla kiitollisia / eikä pyrkiä kumoamaan sitä yhteiskuntaa / joka on meidät kasvattanut." (Saarikoski 1969: 79) Min översättning: "Man säger till oss att vi borde vara tacksamma / och inte försöka omkullkasta det samhälle / som har fostrat oss." 
I Pentti Saarikoskis diktsamling från samma år, Katselen Stalinin pään yli ulos, ordnas också ett demonstrationståg med plakat, flaggor och slagord. "VIET-NAM SIG-RAR!" skanderar deltagarna i demonstrationen på Island (Saarikoski 1969: 38). Diktjaget deltar i tåget under sin två veckor långa vistelse på ön, där den amerikanska militärbasen och NATO-fartyg utgör påminnelser om kalla krigets närvaro. Diktjagets vänsterengagemang präglas av reflektioner och kritiskt ifrågasättande, även av det meningsfulla i själva protesten:

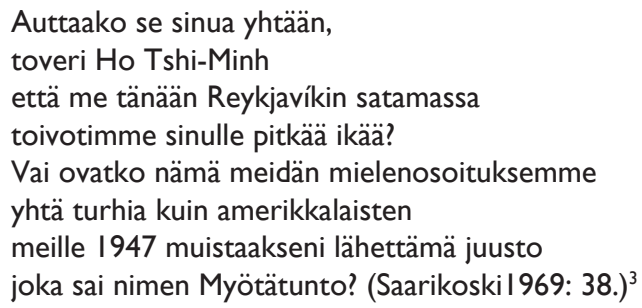

Hô Chi Minh var en revolutionär kommunistisk ledare och president för Nordvietnam under åren 1945-1969 som arbetade för ett självständigt, enat och kommunistiskt Vietnam. ${ }^{4}$ Saarikoski verkar syfta på Marshallhjälpen, USA:s återuppbyggnadsprogram för det krigshärjade Västeuropa som genomfördes 1948-1952, med undantag för Finland som avstod från hjälpen till följd av sovjetiskt motstånd. ${ }^{5} \mathrm{I}$ jämförelse med Saarikoskis dikt (som inte enbart behandlar demonstrationståget och inte heller är avgränsad från de övriga dikterna i samlingens första del utan snarare flyter samman i en pågående monolog) är Anderssons dikt mycket mera tematiskt sammanhållen och kompositoriskt inriktad på en poäng. Bredvid Saarikoskis något cyniska hållning framstår tilltron till det goda hos människan som det utmärkande för Anderssons dikt.

Man kunde också jämföra med Göran Palms "Spegelbilden" ur Världen ser dig från 1964, där perspektivbytet är centralt men sker på ett omvänt sätt. Den unge studenten i Uppsala ska bort en lördagskväll och skyndar iväg mot bussen. Han har hunnit raka sig men känner sig osäker på att hår och annat är som det ska. Han hittar inget ställe att spegla sig i, men tänker på en spegel utanför blomsterhandeln nära Nybrons hållplats som sin sista chans. När han kommer dit är det ändå inte sig själv han ser: "Jag såg en buss. / En buss med ganska mycket folk passerade i spegeln.” (Palm 1978: 505.) Insikten som den upplevelsen föder artikuleras inte explicit men läsaren förstår att jagperspektivet vidgas, att medvetenheten om världen kommer in. I Anderssons dikt sker det omvända: först finns kollektivet och samhället, sedan den unika individen. De nedärvda och ibruktagna idealen från den franska revolutionen - frihet,

\footnotetext{
${ }^{3}$ Min översättning: "Hjälper det dig alls / kamrat Hô Chi Minh / att vi idag i Reykjavíks hamn / önskade dig ett långt liv? / Eller är vår demonstration / lika fåfäng som amerikanernas / ostförsändelse till oss 1947 om jag minns rätt / den som kallades Medlidande?". ${ }^{4}$ Wikipedia, "Ho Chi Min", http://en.wikipedia.org/wiki/Ho_Chi_Minh (hämtat 30.3.2015).

${ }^{5}$ Uppslagsverket Finland, "Marshallhjälpen", http://www.http://uppslag.kaapeli.fi/bin/view/ Uppslagsverket/Utrikeshandel (hämtat 16.12.2015).
} 
jämlikhet och broderskap ${ }^{6}$ - rubbas inte som sådana men tillämpningen av dem, de praktiska politiska yttringarna, ifrågasätts. Solidariteten kan inte verkställas efter schabloner och kategorier utan måste beakta verklighetens mångfald.

"Solidaritet" är nära förbundet med begrepp som "gemenskap" och "socialism". Ingvar Johansson diskuterar dessa begrepp i marxistisk filosofi:

\begin{abstract}
Traditionellt sett har socialister haft en föreställning om kollektiva beslut som idéhistoriskt knyter an till Rousseaus tankar om en allmänvilja. Gemenskapen skulle vara tät. Vad ett verkligt kollektiv vill ska vara sådant att vad jag vill det vill också den andre, och vad den andre vill det vill också jag. Dessutom ska jag vilja vilja vad den andre vill, och den andre ska vilja vilja vad jag vill. Och detta gäller alla. Gemenskapen är total. Det finns ingen individualistisk avvikare, men inte heller någon som försöker bestämma över någon annan.

Så fort man belyser denna extrema form för gemenskap, så spricker den ur socialistisk synpunkt. Den tillåter inte ens vanliga splittrade demokratiska omröstningar, och den kan på sin höjd existera i det som i modern sociologi kallas primärgrupper. Socialismens gemenskap är däremot hela mänsklighetens gemenskap. Och den kan bara vara tunn. Den måste rymma former för individualism. (Johansson 2007: 97.)
\end{abstract}

Slutsatsen att gemenskapen måste ha plats för individualism är densamma som Claes Anderssons. I sin självbiografiska bok Mina tolv politiska år (2000) tar han upp intoleransen i det tidiga 70-talets mest sekteristiska maoistiska aktionsgrupper. Där uppfattades till exempel skönhetsupplevelser som a priori reaktionära. Andersson berättar om en ung flicka som blev utfryst ur sin egen grupp när hon uttryckte sina lyckokänslor över våren och blomsterprakten en majmorgon på Salutorget i Helsingfors: "Det var så vackert, så otroligt vackert!". Hennes glädjeyttring bemöttes med iskall tystnad, hon fråntogs sina förtroendeuppdrag och behandlades därefter som luft. (Andersson 2000: 123.) Den vardagens fulhet som bland annat Sonja Åkesson gjorde verkningsfull poesi av blev en del av 1960- och 70-talens estetik - och rentav en "samtida grogrund för sammansmältning, gemenskap och demokrati”, som Amelie Björck (2008: 42) uttrycker det. Men det exempel ur verkligheten som Andersson ger påminner om att frigörelsen från borgerliga skönhetskonventioner i sig själv kunde bli konform och förtryckande.

"Det godaste ord jag vet är: oss", skriver Andersson i diktsamlingen Samhället vi dör i (1967: 10). I samlingen överlag kopplas solidaritetstanken samman med någonting kroppsligt, biologiskt och sexuellt. Recensenten Kristina Rotkirch påpekar i Nya Argus att Samhället vi dör $i$ är den första diktsamlingen av Andersson som är genomsyrad av samma krävande världs- och sociala engagemang som FBT och att den samtidigt rymmer mera livslust än någon av de tidigare. Hon lyfter särskilt fram kärleksdikterna "explosiva 'vi'-upplevelse" som hon menar har sin klara anknytning till "idéplattformens solidaritetskrav." (Rotkirch 1967: 176.) En av kärleksdikterna lyder så här:

"I Anderssons nyårsdikt, "Dikt till 70-talet", skriven för Finlands rundradio och uppläst i radio den 31 december 1969 sätts den franska revolutionens slagord i prioritetsordning: "Jämlikhet. Broderskap. Dessa måste först förverkligas / innan friheten, från svält och maktlöshet, blir verklighet”. Dikten publicerades i Finsk Tidskrift 1970: 3, I I4. 


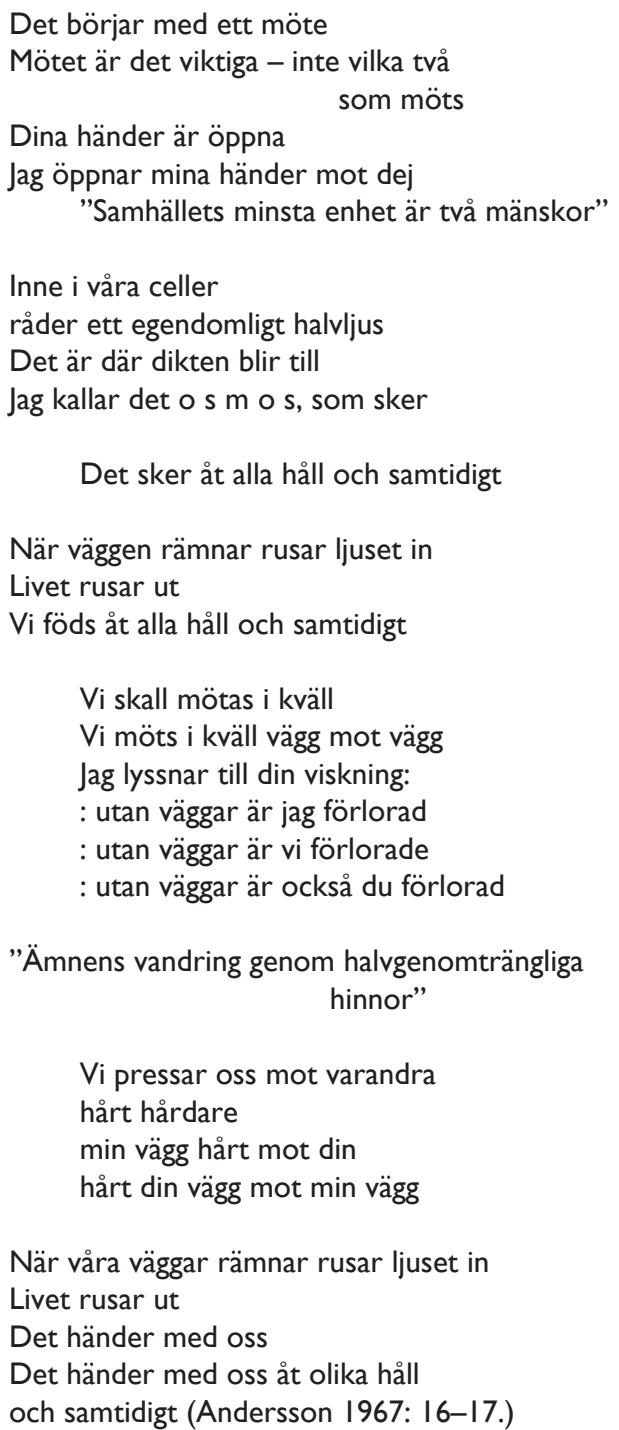

Ett centralt ord i dikten är "osmos". Det definieras i Nationalencyklopedin som "transport av lösningsmedel mellan två faser med olika koncentration av upplösta ämnen och där faserna är åtskilda av ett membran som endast släpper genom lösningsmedlets molekyler." Sådana membraner kallas semipermeabla; alla membraner som finns i levande celler är av detta slag. ${ }^{7}$ Den fonetiska likheten mellan ordet "oss" och "osmos" är uppenbar och fungerar som en påminnelse om den språkliga och materiella dimensionen i diktens centrala metaforik. Det metapoetiska elementet uttalas också tydligt: osmosen har med diktandet att göra.

Utsagorna inom citattecken låter nästan som om de kunde vara tagna ur en samhällsvetenskaplig respektive naturvetenskaplig facktext. Åtminstone implicerar citattecknen i sig att det är fråga om en text $\mathrm{i}$ texten, en form av collageteknik. Ändå blir de inga stilistiska avvikelser utan smälter samman med den övriga texten och ter sig kongeniala med diktrader som "När väggen rämnar rusar ljuset in / Livet rusar ut", där assonanser och allitterationer ger orden eufoniska kvaliteter. Det är det lyriska textsammanhanget som ger de facklitterära citaten (konstruerade

${ }^{7}$ Nationalencyklopedin, "osmos", http://www.ne.se/uppslagsverk/encyklopedi/lång/osmos (hämtat 12.2.2015). 
eller verkliga) deras valör - som sådana eller $i$ ett annat sammanhang skulle de framstå på ett annat sätt. Det blir därför ett "möte" även på en metapoetisk nivå: ett möte mellan olika diskurser, en konfrontation som påverkar bägge.

Det finns en viktig homonym glidning i dikten. I början öppnar duet och jaget sina "händer" mot varandra, i slutet av dikten "händer" något med dem båda. Ordet byter ordklass men det viktiga är att handling övergår i händelse. Till strukturen är dikten dialektisk, i bemärkelsen en process som utvecklas genom en tes, dess antites och ur denna motsättning en syntes. Den "dialektiska metoden" hos Andersson har diskuterats i tidigare forskning som ett centralt grepp i hans poesi (se Laihinen 197I; Zilliacus 1972). I denna dikt framskrider den dialektiska processen från separata identiteter till en ny helhet. Detta åskådliggörs på det formella planet bland annat genom varierade konstellationer av pronominen du, jag, min, din, vi, oss: parallellism ("utan väggar är jag förlorad", "utan väggar är vi förlorade"), kiasm ("min vägg hårt", "hårt din vägg"), tempusförskjutning ("Vi skall mötas", "Vi möts") och upprepning ("Det händer med oss"). De fyra gånger upprepade kolonen fångar typografiskt upp idén om de genomsläppliga väggarna.

Tematiskt kan man i diktens behandling av oss, osmos och möte se en gestaltning av tanken om solidaritet. Diktens motto "Mötet är det viktiga - inte vilka två som möts" har att göra med kärlek mellan människor allmänt taget och inte med den romantiska kärlekens unika och exkluderande vi. Ändå är det uttryckligen en kroppslig, biologiskt förankrad människokärlek och inte kristendomens agape-kärlek. Den i grunden fysiska och därför också sexuella kärleken blir en metafor både för konstnärligt skapande och för social gemenskap på samhällsnivå. Anderssons dikt skildrar (kärleks)mötets ambivalens och hot mot den enskildes identitet och existens, men bejakar det som en nödvändig och naturgiven existentiell utmaning. Att människor möts är oerhört och omstörtande. Just så farligt och radikalt måste det få vara. Ur det mötet genereras nytt liv, i begreppets vidaste bemärkelse: i poesin, i samhället. Solidaritet kan inte förverkligas som en princip utan det är något som sker med "oss".

Samhället vi dör $i$ är en antitetisk titel som anspelar på Ragnar Meinanders lärobok i samhällslära för svenska skolor i Finland, Samhället vi lever i. Genom allusionen sätts lyriken i förbindelse med facklitteratur och ett verkligt samhälle, vilket är en del av Anderssons och FBT:s poetik. ${ }^{8}$ Men intertextualiteten kan i ett efterhandsperspektiv även tillföra andra aspekter. Meinanders lärobok gavs ut i ett flertal omarbetade upplagor genom åren och det är intressant att se vilka ideologiska förskjutningar som äger rum och vilken kontext som Andersson relaterade till.

Om man jämför den sjätte omarbetade upplagan från 1965, det vill säga den som användes i skolorna vid den tid när Anderssons diktsamling Samhället vi dör $i$ kom ut med en senare reviderad version från

${ }^{8}$ Andersson (1965:I, 2I) skriver i en FBT-artikel att poesin inte ska välja bort något utan välja till, bl.a. relationen till samhällsvetenskaper och språkforskning. 
1978, som Meinander skrivit tillsammans med Göran Selén, ser man att perspektivet förändrats. I upplagan från 1965 finns ett förord, där huvudtanken är att medborgaren i ett demokratiskt samhälle bör ha tillräckliga kunskaper om samhällsskicket för att kunna axla sitt ansvar och "fatta en självständig ståndpunkt till samhällsfrågorna" (opag.). Syftet med boken är därför att ge en sådan nödvändig orientering i samhällslivet i dåtidens Finland. I upplagan från 1978 anläggs däremot ett tydligt solidaritetsperspektiv. Hela framställningen startar med definitioner på "samhälle" och "stat", som tar fasta på relationerna mellan individer och på det sociala livet. En etymologisk förklaring ges även: ordet "samhälle" uppges gå tillbaka på det fornsvenska "samhælde" som betyder sammanhållning. I marginalen finns dels en definition på "solidaritet" som "gemensam ansvarighet, sammanhållning, kamratskap", dels ett citat av Thomas av Aquino från cirka 1264, där han säger att människan "av naturen [är] en varelse som skapats att leva i samhälle och stat och som lever i gemenskap långt mer än alla andra varelser." (Meinander \& Selén 1978: 8.) ${ }^{9}$

Det som man kan konstatera vid en jämförelse mellan upplagorna från 1965 och 1978 är att föreställningen om solidaritet som någonting konstituerande för samhället och demokratin saknas i den tidigare versionen (som istället betonar kunskapens vikt) men finns helt utvecklad i den senare versionen. Det sätter också Anderssons diktsamling i ett sammanhang som synliggör hur poesin formulerar ett nytt tänkesätt som först senare etableras och sanktioneras av utbildningssystemet. Poesin är steget före - men ännu viktigare är att den kan fungera som ett komplement och korrektiv när ideologiskt tänkande implementeras i ett samhälle. Inte minst genom att lämna frågor öppna.

Enligt Clas Zilliacus (1972: 28) har "skenmotsättningen mellan individ och samhälle" tagits av daga i Samhället vi dör i. Men motsättningen mellan individ och samhälle är ändå inte överspelad i Anderssons poesi - frågeställningen är komplicerad och återkommer i senare dikter. "Det känns ofta fel att älska och bli älskad / när så många står utanför alla möjligheter" skriver han i Det är inte lätt att vara villaägare i dessa tider och problemet som anfäktar jaget har att göra med frestelsen att utesluta sådant ur medvetandet som grumlar den privata lyckan, det vill säga andras otrygghet och nöd (Andersson 1969: 27). Men i en dikt ur Bli, tillsammans räknas kärleksparets samlag tvärtom in i mänsklighetens totala lycka, som därmed ökar: "Vi ligger ihop du och jag / och det är en tröst att tänka på / att inte alla mänskor har det illa / på jorden, just i denna stund". Medvetenheten om att kärleksakten pågår medan "Asiens buk sväller av hunger" finns ändå med; det globala perspektivet med kroppslig konkretion. (Andersson 1970: 29.) Exemplen visar att Andersson inte lyckas ge det förlösande, slutgiltiga svaret på solidaritetens problem i sin

\footnotetext{
9 I brödtexten sägs att "Samhället är människorna i familjen, i kommunen, i Finland, de olika grupperna av människor med deras samarbete och gemensamma intressen." T.o.m. Daniel Defoes roman om Robinson Crusoe anförs som exempel på hur många svårigheter den enskilde kan råka ut för "just för att han levde ensam på sin öde ö utan att vara samhällsmedlem tillsammans med andra människor." (Meinander \& Selén 1978: 8.) Oftast brukar Robinson Crusoe uppfattas som en personifikation av den rationella och självständiga individen som reder sig på egen hand med hjälp av sin intelligens och handlingskraft.
} 
poesi, men det är också i det fortsatta sökandet och tvivlandet som det ideologiska engagemanget hos honom blir dikt och inte dogm.

\section{Urban anonymitet}

"Han är en mycket ensam mänska / Därför vet så få om det" - så lyder en aforistisk kortdikt av Andersson (1979: 28) som fångar en aspekt av det urbanas problematik. Vad 1960- och 70-talens urbanitet och samhälleliga strukturomvandling innebär på individnivå är ett tema som han belyser i många dikter. Om Finlands huvudstad skriver han bland annat "Helsingfors kan man älska / för dess vanlighet, för dess brist / på anletsdrag, dess likgiltighet / för dem som faller omkull på gatorna / och blir liggande" (Andersson 1970: 14). Det är en ironisk kärleksförklaring som synliggör det tvivelaktiga både i det som liknar ett flanörsperspektiv och i den "vanliga" storstadens förhållningssätt till sina invånare. Clas Zilliacus betraktar precis som Kristina Rotkirch Anderssons diktsamling Samhället vi dör $i$ från 1967 som en vändpunkt i författarskapet. Poetiken har i denna fjärde samling hunnit ifatt poetiken från $F B T: s$ manifest och vid en jämförelse med de nya dikternas historiemedvetenhet - en förståelse för att "[s]amhället har strukturella fel: dess brister beror inte på att starka individer sätter sig på svaga utan på att systemet har gjorts sådant" - ter sig de föregående samlingarna "som tidsmedveten flanörpoesi". (Zilliacus 1972: 27.) ${ }^{10}$ De dikter som kommer att diskuteras i det följande är från 1967 eller senare och anlägger ett sådant historiemedvetet och samhällskritiskt perspektiv som de samtida kritikerna lyfter fram.

I Rumskamrater skriver Andersson om storstadens eller förortens barn:

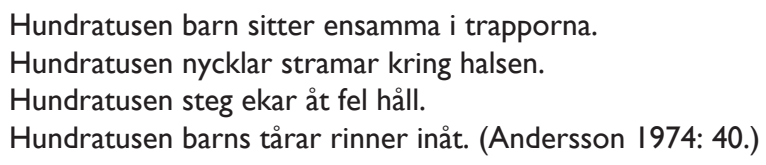

Dikten kan jämföras med Nils Ferlins kända dikt från 1933, som börjar så här: "Du har tappat ditt ord och din papperslapp, / du barfotabarn i livet. / Så sitter du åter på handlarns trapp / och gråter så övergivet." (Ferlin 1985: 630.) Men i Anderssons dikt är det inte ett enskilt barn som sitter på en särskild trappa i sin ensamhet och gråter utan en anonym massa $i$ anonyma höghustrappor medan föräldrarna är upptagna i förvärvslivet den konkreta situation som beskrivs är innehållsligt elliptisk men lätt att fylla ut med detaljer ur en igenkännbar 70-talskontext.

Förorten var ett hett ämne i den offentliga diskussionen på 1960och 70-talen och något som i hög grad associerades med sociala problem. Journalister, författare, planerare och samhällsforskare framförde

\footnotetext{
10 Samhället som vi dör i betraktas av flera - med rätta - som en vändpunkt. T.ex. av recensenten Sören Lindgren som jämför denna samling med den föregående: "I 'Staden heter Helsingfors' berättar Claes Andersson fortfarande om ensamma och utstötta, men nu tillskriver han inte längre individen huvudansvaret utan samhället och systemet." Han nämner också att den faktor som tillkommit är "ett historiemedvetande". Vasabladet 24.9.1967.
} 
likartad kritik som hade att göra med att anpassningen till industrialiseringen och strukturomvandlingen inte hade lyckats: människor i förorterna var lösryckta från sina rötter, hade inte kontakt med varandra och led av en ökad osäkerhet (Kortteinen 1982: II-I4). I sin sociologiska studie Lähiö (1982, Förorten) frågar sig Matti Kortteinen hur det egentligen förhåller sig, om förortens rykte har motsvarighet $i$ verkligheten. Han finner att bilden behöver nyanseras bland annat ifråga om den påstådda bristen på kontakt. Åtminstone den stora gruppen barnfamiljer visade sig i hans material utveckla sociala nätverk kring sandlådan, bastukvällar, talkoarbete och dylikt. Förortens största grupp var just barnfamiljer, vilkas liv präglades av uppdelningen i förvärvsarbete och fritid. Uppspaltningen av tillvaron - som Kortteinen sätter i förbindelse med den patriarkala kulturens kris - tillsammans med den impulsfattiga boendemiljön (och naturligtvis livsfasen i sig) gjorde familjelivet helt centralt. (Kortteinen 1982: 233.) Förorten betraktar han framför allt som ett arbetskraftsreservat; som ett sådant var den planerad och som ett sådant fungerade den (Kortteinen 1982: 56). Men konsthistorikern och genusforskaren Kirsi Saarikangas lyfter hellre fram de positiva sidorna av förorten:

\footnotetext{
Både i planeringen av förorten och i det praktiska boendet betonades en boendeform som byggde på kärnfamiljen. Man ansåg att förorterna utgjorde sundare boendemiljöer och det omfattade både bostaden som var välplanerad och utrustad med moderna bekvämligheter, och själva miljön, som i motsats till innerstaden var öppen och naturnära. Målet var barnens bästa och att göra vardagen enklare för barnfamiljerna. (Saarikangas 2010: 87.)
}

Enligt Saarikangas expanderade kvinnornas livsmiljö från hemmet till gården och närmiljön. Genom sina dagliga sysslor och rörelser skapade kvinnorna ett eget utrymme och började ha kontroll över sin omgivning. Mammorna var för det mesta hemmafruar, men en del började förvärvsarbeta när barnen kom upp i skolåldern. Organiseringen av den offentliga barnomsorgen var dock inte helt anpassad efter denna nya situation. Skolelever kunde därför få gå omkring efter skoldagen "med en nyckel om halsen" tills föräldrarna kom hem efter sina jobb. (Saarikangas 20l0: 91.)

I ett efterhandsperspektiv kan man alltså konstatera att Anderssons dikt om de hundratusen ensamma barnen återspeglar den negativa allmänna opinion mot förortsmiljön som uttrycktes offentligt i samtiden - det är först senare forskning som lyft fram positivare sidor. Diktens barn har lärt sig att hålla inne med sin smärta. Det finns ju ändå ingen som svarar eller reagerar på deras nöd. Den anaforiska strukturen förstärker intrycket av den inrutade vardagens monotoni och av det särskilda barnets osynlighet bakom statistiska siffror. Ferlins dikt har till skillnad från Anderssons en strof till där någon - diktarrösten eller en tänkt förbipasserande vuxen - ställer frågor till barnet $\mathrm{i}$ ett halvhjärtat försök att göra något "förrn vi föser dej bort". I Anderssons dikt finns inte ens en sådan personlig om än otillfredsställande kontakt. Den borttappade lappen i Ferlins dikt antyder att det funnits ett uppdrag för barnet och någon som väntar där hemma, kanske med bannor. I Anderssons dikt finns istället en nyckel och barnets uppdrag är att sköta sig själv. 
I en intervju i Kyrkpressen 1979 säger Andersson att den snabba strukturförändringen har skapat två nya samhällstyper: tätortsslummen i storstädernas förorter och den avbefolkade landsbygden. Om den förra konstaterar han: "De är ofta snabbt och dåligt uppförda och där fungerar service och kultur väldigt illa. Förorterna är också ofta dåligt planerade för barn och ungdom." Han kommenterar samhällsutvecklingens konsekvenser för familjen. Produktionsförhållandena idag "kräver att familjen ska vara liten och lättrörlig och att man måste prioritera arbetet framom familjen. I - Men små lättrörliga familjer är väldigt sårbara, för där finns så lite människorelationer. Och det är ju människorelationerna som uppfostrar oss människor och skapar vår trygghet." Enligt Andersson korrelerar sjukdomar negativt med graden av integration i samhället. Om människor inte trivs eller lever $i$ ett vettigt sammanhang så ökar förekomsten av psykiska störningar, alkoholism, användningen av droger med mera. Men detta är bara ytbilden av de konsekvenser som ett dåligt fungerande samhälle medför; också människors sätt att uppleva sig själva, "sin identitet, sitt människovärde, sina påverkningsmöjligher, andra människor osv" förändras. (Appel 1979.)

I samhällsvetenskaplig forskning har "alienation" varit ett viktigt begrepp. För Hegel innebar alienation en åtskillnad mellan människan som skapande subjekt och människan som objekt, påverkad och manipulerad av andra. Det som människan har skapat (språk, vetenskap, teknik och så vidare) befinner sig utanför henne som främmande objekt och förtingligade relationer. I marxistisk teori sätts alienationen i förbindelse med det kapitalistiska systemet; människan som av naturen vill förverkliga sig själv genom arbete hindras av den kapitalistiska produktionen att göra detta. Arbetet blir något avskilt och främmande som människan inte har kontroll eller överblick över." En sida av alienationen är också massisoleringen. Arnold Ljungdal beskriver den som en "total ensamhets- och övergivenhetskänsla hos den enskilde som står i en paradoxal kontrast till den runt omkring oss pågående urbaniseringen och anhopningen av människor i allt större bostadsenheter." Han hänvisar också till den amerikanske sociologen David Riesmans bok Den ensamma massan, som blivit en klassiker och vars titel snabbt blev ett slagord. (Ljungdal 1967: 40.) I en dikt ur Anderssons samling Samhället vi dör i åker diktjaget buss i "rusningstid i Norden" och tänker på den förutspådda globala befolkningsexplosionen och på att man i Indien använder samma ord för trivsel och trängsel: "Kanske dom tagit fel / Kanske är det trivsel dom menar / är det trösterikt att tänka på” (1967: 59).

Den anonyma individen i en bostadsmiljö utan särdrag får sin tolkning av Andersson i följande dikt ur Genom sprickorna i vårt ansikte:

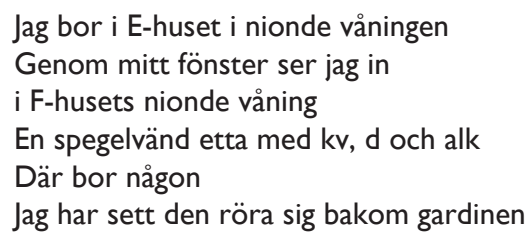

" Nationalencyklopedin, "alienation”, http://www.ne.se/uppslagsverk/encyklopedi/lång/ alienation (hämtat 13.2.20I5). 


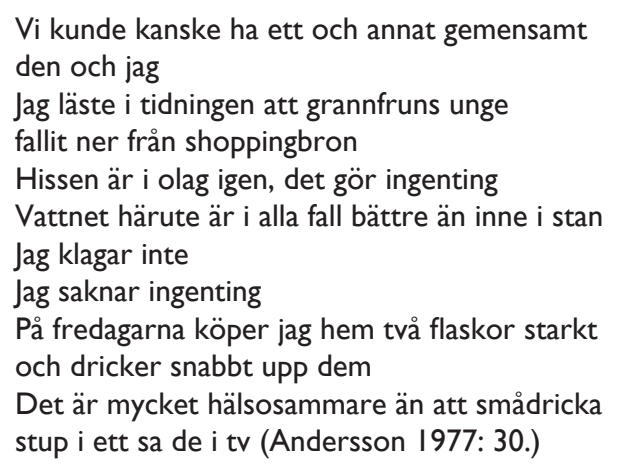

I beskrivningen av sitt eget hem som en etta $\mathrm{i}$ E-husets nionde våning med, precis som grannhusets motsvarande bostad, "kv, d och alk", röjs individens upplevelse av alienation. Perspektivet är ett yttre och terminologin standardiserad och maximalt avpersonifierad och reduktiv $i$ de förkortade formerna för kokvrå, dusch och alkov. Läsaren informeras inte om diktjagets kön, ålder eller yrke men av hållningen och vanorna att döma kunde det handla om en manlig pensionär, kanske sjukpensionär? Det är ofta manliga öden som Andersson tar upp i sin poesi. Som tidigare nämnts är förortsmiljön enligt Matti Kortteinen förbunden med patriarkatets kris. Han menar, i likhet med Kirsi Saarikangas, att förorterna under 1960- och 1970-talen i flera avseenden stärkte kvinnornas ställning, men försatte männen i ett sämre läge. Det blev oklart vilken mannens position var $\mathrm{i}$ en förortsfamilj där båda parter förvärvsarbetade men kvinnan ändå bar hela ansvaret för hemlivet. Männens upplevelse av frustration och av att inte behövas kanaliserades lätt $\mathrm{i}$ alkoholism. (Kortteinen 1982: 238.) Förortens stimulansfattiga omgivning och dess uppdelning i olika sfärer innebar också särskilda utmaningar för dem som inte kunde knyta sociala kontakter via barnens lekar på gården, såsom ensamma pensionärer. Deras vardag kunde enligt Kortteinen bli verkligt tröstlös. Han citerar en 64-årig sjukpensionär: "Eihän täällä muuta voi ku juoda kaljaa ja kävellä.” (Kortteinen 1982: 48.) Dricka öl och promenera var det enda man kunde ta sig för.

Det naturliga intresset för grannen mitt emot blir i Anderssons dikt något ofruktbart i denna gemensamma miljö, där det fysiska avståndet gjorts så litet men arkitekturen och omgivningen sådan att spontant kontakttagande i praktiken förhindras. Mannen saknar barnfamiljens möjlighet att överskrida miljöns begränsningar. Det går inte an att bara ringa på och presentera sig - förortens sociala koder medger inte det. Grannen är nära men oåtkomlig, omöjlig att identifiera ens till genus, det är "någon" som bor där, "den" rör sig bakom gardinen. Intrycken som diktjaget får kommer via massmedier. Vad som händer grannarna får han reda på via tidningen, förutsatt att det som hänt är tillräckligt dåligt för att passera nyhetströskeln. Tv:n informerar om hur man lever hälosamt och åtminstone i diktjagets avsiktliga feltolkning av det rekommenderade alkoholbruket finns ett mått av humor och individuell frihet, visserligen en destruktiv sådan. Förnöjsamheten och det positiva tänkandet (vattnet är bättre än i stan, det gör inget att hissen är i olag igen) förstärker intrycket av den lilla människans maktlöshet inför ett övermäktigt samhällssystem. $\mathrm{Om}$ han saknade något, om han klagade, 
vilken skillnad skulle det göra? Den dåliga kvaliteten på husen i förorten är för övrigt en av aspekterna som Kortteinen tar upp - listan på behövliga reparationer efter en husgranskning kunde vara lång (Kortteinen 1982: 35).

I flera sammanhang $\mathrm{i}$ offentligheten påpekar Andersson hur farlig ensamheten är för människan. I samband med ett framträdande för Röda Korsets väntjänstkurs i Lovisa 1977 säger han att alla behöver andra människor för att bli människor och att "[d]en människa som drar sig bort från mänsklig gemenskap blir sjuk. Sjukdom kan egentligen definieras som ensamhet" (Grefberg 1977). Anderssons dikter om barnen i trapporna och mannen i E-husets nionde våning ger uttryck för att denna ensamhetens sjukdom drabbar individer $\mathrm{i}$ de förorter som byggs upp i samtiden.

Alkoholister och uteliggare är också en kategori i storstadsmiljön som engagerat Andersson som politiker, läkare och poet, och i hans arbete inom den tidigare nämnda Novemberrörelsen. I dikten "Fall 220" ur Det är inte lätt att vara villaägare $i$ dessa tider blir de sista raderna ett slags lyriskt epitaf: "Här sover Veka / Roskislådans konung / Tarzans överman / Rolig som helvete / Snäll som ett lamm / Död som en mänska" (Andersson 1969: 45). Man kan jämföra med Anna Maria Lenngrens ironiska I700-talsdikt "Epitaf" om militärens livsgärning:

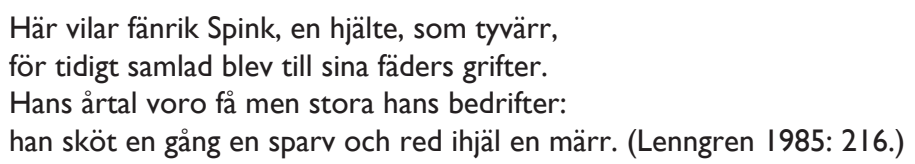

Anderssons dikter lockar ofta till skratt men inte i "Fall 220". Det finns inget skrattretande i uteliggarens misslyckade liv och olyckliga död, till skillnad från minnesbilden över fänriken i Lenngrens dikt. Medan det komiska med fänriken är diskrepansen mellan å ena sidan den offentliga retoriken och den sociala uppburenheten och å andra sidan hans faktiska liv så gäller det omvända i Anderssons dikt. Allvaret uppstår då "puliukkon" lyfts upp till ett lyriskt motiv och framstår som en unik människa med ett namn och en personlighet. ${ }^{2}$ I en annan dikt skriver Andersson "Det finns ingen skuld, bara de / som vägrats förutsättningarna" (I979: 15). Det låter som ett motto $i$ överensstämmelse med den hållning som man finner överallt $i$ hans poesi och $i$ hans offentliga ställningstaganden. I en intervju i Astra 1976 säger Andersson att alkoholismen har att göra med de snabba samhällsförändringarna; med industrialisering, urbanisering och kulturförändringar. Arbetsmarknaden har inte plats för "puliukkorna". (Mandelin-Dixon 1976: 8.) Arbetslöshet och alkoholism tematiseras också i dikten "Blandekonomi” ur Bli, tillsammans:

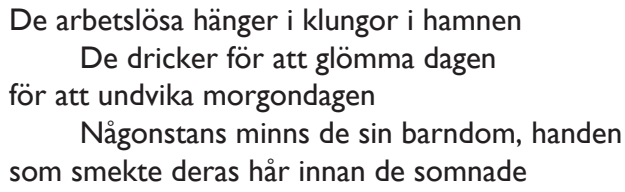

\footnotetext{
12 Andersson använder i intervjuer ofta den finska benämningen "puliukkor" vanlig även i finlandssvenska - för bostadslösa alkoholister, men utan någon nedlåtande innebörd.
} 


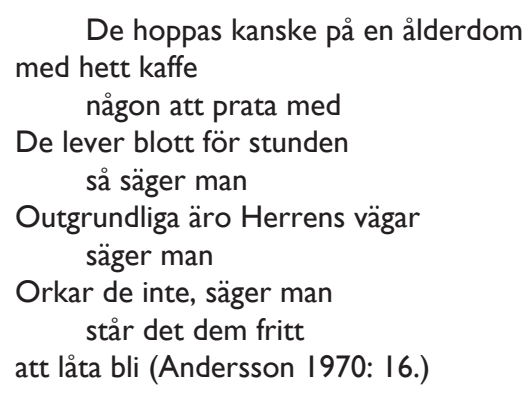

Det anaforiska "De" och upprepningen "säger man" tillsammans med lineationen, där varannan rad är indragen markerar skillnaden mellan två grupper (även om radens placering och innehållet inte sammanfaller på något kategoriskt sätt): socialfallen och ordentliga medborgare. Därtill kommer den implicita författaren, en instans i texten som sympatiserar med de utslagna och intar en kritisk hållning till cynismen och självgodheten hos det normerande kollektiv och den allmänna, borgerliga opinion som ryms i "man" som "säger" det ena och det andra. Påståendet att "De lever blott för stunden" röjer samma attityd som den ordentliga myran har till den sorglösa syrsan i Jean de La Fontaines kända fabel. När syrsan ber om bröd av sin granne får hon som svar: " 'Vad har fröken sommarn lång / sysslat med för näringsfång?' / frågar hon den medellösa. / 'Ack jag sjöng, min bästa fru, / sjöng som syrsor göra!' / 'Sjöng ni? Fägnar mig att höra. / Då får fröken dansa nu!' " (La Fontaine 1959: 23.) Den andra invändningen mot de sysslolösa klungorna i hamnen handlar om att förskjuta ansvaret på en allsmäktig gudomlig instans, vars beslut det inte anstår en människa att ifrågasätta. Vissångaren Cornelis Vreeswijk ironiserar också över en sådan attityd i sin kända sång från 1968: "Somliga går med trasiga skor, säg vad beror det på? Gud Fader som i himmelen bor kanske vill ha det så." I Anderssons dikt är det blandekonomin - detta är diktens titel - det vill säga det nordiska samhällssystemets kombination av plan- och marknadsekonomi som åstadkommer fenomenet med drickande arbetslösa och som genererar allmänna åsikter om detta fenomen, vilka samtliga går ut på att frånta sig själv (som privilegierad individ) allt ansvar.

I följande dikt av Andersson ur Rumskamrater tematiseras förhållandet mellan individens medvetande och det samhälle han lever i:

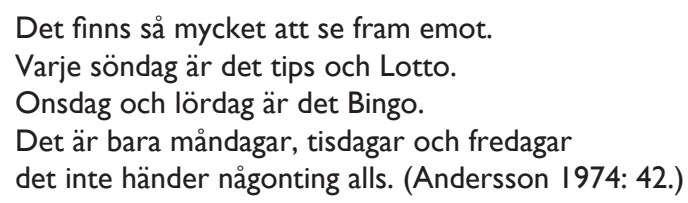

Det är en rolldikt präglad av lakoniska konstateranden i liknande anda som $\mathrm{i}$ dikten om mannen $\mathrm{i}$ E-huset. Det inledande påståendet som låter förstå att det finns möjligheter och utblickar motsägs av den inrutade och andefattiga tillvaro som sedan beskrivs. Det är ett tragikomiskt snävt perspektiv som åskådliggörs med tillrättalagda folknöjen som förleder till initiativlöshet, fantasilöshet och beroende. Tips, lotto och bingo handlar om spänningen $\mathrm{i}$ att spela men också om hoppet att något plötsligt ska hända och ändra på allt. Vinsten i sedlar och mynt framstår som 
det ständigt förnyade lockbetet. Som vanligt lyckas Andersson framställa diktjaget som sympatisk i dennes raka, oförställda kommunikation och tillitsfulla anpassning. Det tvivelaktiga finns i systemet som förkrymper och förvanskar hans medvetande.

Enligt Marx är det inte människans medvetande som bestämmer hennes vara utan hennes samhälleliga vara som bestämmer hennes medvetande (Jonsson 1998: 102-103). Svante Nordin redogör i Marxismens filosofi (2007) för hur pengar och medvetande hör ihop utgående från Alfred Sohn-Rethels resonemang:

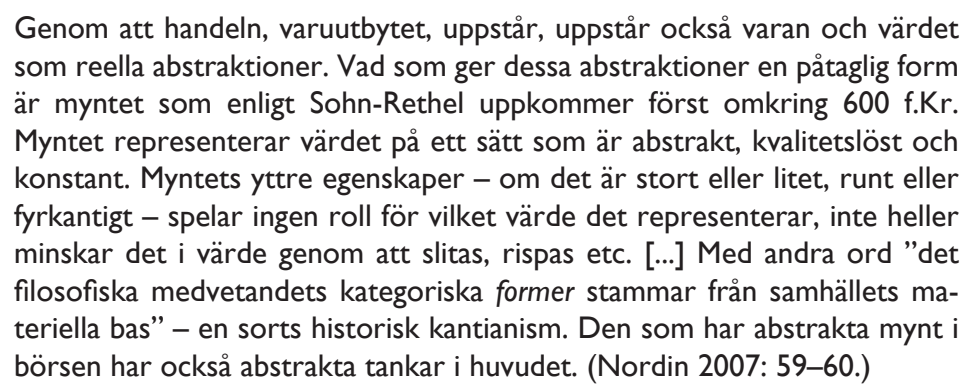

Anderssons dikt kan ses som en konkret gestaltning av vad det innebär att samhällets materiella bas formar dess andliga överbyggnad. De tillbudsstående aktiviteterna - så upplever diktjaget situationen - har att göra med spel om pengar, en verksamhet som är konstruerad för att upprätthålla begäret att ännu en gång pröva sin lycka, och ännu en gång. Genom att Andersson låter det ekonomiskt abstrakta i människors vardagsliv representeras av något så påtagligt, avgränsat och karikerat som spelberoende synliggörs människans deformerande relation till de materiella omständigheterna i det kapitalistiska systemet. Diktjaget har inget oberoende, fritt medvetande att sätta upp mot sitt samhälles andliga förtryck och mekaniska manipulation, för han är själv en inkorporerad del av sin kultur. Diktens samhällskritik är outtalad men närvarande i det ironiska porträttet. Att inte författaren heller förmår ställa sig utanför sin kulturs medvetandeformer och konstruerade behov både bekräftar och komplicerar bilden. Andersson betraktar sig själv (åtminstone sedan han blivit pensionär) som spelgalen och beskriver sig som en trogen besökare av spelhallen Täyspotti i Hagalund i Helsingfors (2000: 142-143).

\section{Psykiatrin som samhällets röntgenbild}

I Bli, tillsammans finns följande dikt ur en psykiatrisk verklighet:

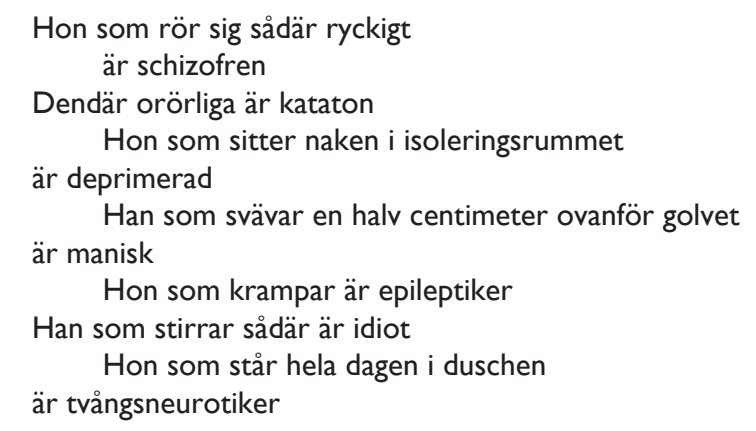


Han som hängt sig är död

De som förvånade betraktar allt detta

är personalen (Andersson 1970: 42.)

Individerna är prydligt inordnade under diagnostikens etiketter utgående från iakttagbara symptom. Patienterna förevisas som anonyma och avhumaniserade objekt på ett "vetenskapligt" avstånd samtidigt som sättet att beskriva dem är talspråkligt och ignorant: sådär, dendär. Absurditeten i det kategoriserande förhållningssättet blir uppenbar senast i slutet av dikten, där listandet av patienter och symptom fortsätter med iakttagelsen att "Han som hängt sig är död". Inget i diktens form, stil eller perspektiv vittnar om att det gör någon väsentlig skillnad huruvida objekten för observationen är levande eller döda. En känslomässig relation till de utpekade och beskrivna saknas i vilket fall som helst. Personalen ingår i schematiseringen och är avpersonifierad i samma mån. Igen en gång drabbar kritiken inte de enskilda människorna som tvingas in i roller och system som förhindrar naturlig empati, mänsklig kontakt och nyanserad förståelse utan den organisationsform som åstadkommer denna skevhet.

Dikten har titeln "Till minnet av Kraepelin" och är tillägnad den psykiatriska diagnostikens fader Emil Kraepelin. Andersson ser sig själv som en företrädare för den radikala antipsykiatrin och som en förespråkare för de nya idéer som R.D. Laing, David Cooper och Franco Basaglia förde fram. Han kallar psykiatrin en röntgenbild som visar "förtryckets och översitteriets mekanismer i samhället." (Andersson 2000: 22, 100.) Enligt Laing i Det kluvna jaget (The Divided Self utgavs ursprungligen 1960) kan den mentalt sjukes beteende betraktas som tecken på en sjukdom (såsom Kraepelin gjorde) eller som uttryck för hans existens (såsom Laing själv gör): "Den existentialistisk-fenomenologiska tolkningen drar slutsatser om hur den andre känner sig och hur han handlar." (Laing 1968: 26-27.) Han menar att tolkningen av patienten måste ses som en funktion av förhållandet till patienten: "Konsten att förstå de sidor av en individs existens som vi kan iaktta, som uttryck för hans sätt att leva i världen, kräver att vi sammanställer hans handlingar med hans sätt att uppleva sin situation i förhållande till oss. På samma sätt måste vi förstå hans förflutna utifrån hans nuvarande situation, inte tvärtom." (Laing 1968: 29.)

Andersson har också tillägnat Laing en dikt, "Fenomenologens dilemma": "Du som tycker dig vara fylld av fluglarver / som tycker dig vara död och stadd i förruttnelse / Du som tror dig vara den klaraste stjärnan på himlen / eller som tror dig bo inne i stenen du smeker / Du som viskar till dig själv inne i stenen / Hur skall jag förstå vad du upplever?" frågar sig jaget (Andersson 1970: 40). Dikten fortsätter med att reflektera över möjligheten att den hjälpande faktiskt vågade dela den sjukes upplevelse och struktureras därefter av ackumulerande frågor: "Och, $v$ å g a $r$ jag den upplevelsen? / Är den inte alltför lockande? / Är det inte alltför mycket liv, att våga? / Och om jag vågade / Vem skulle då hjälpa o s s ? / Eller - finns ordet hjälpa?" (Andersson 1970: 40-4I). Dikten avslutas med ytterligare tre alltmer avskalade frågor om vem, varifrån och vart. Dikten visar att Laings metod inte heller är oproblematisk - redan titeln aviserar detta - men skillnaden $\mathrm{i}$ anda mellan dikten om den kraepelinska psykiatrin och denna är enorm. 
Det fenomenologiska perspektivet gör att representanten för den psykiatriska personalen blir ett existentiellt jag som möter ett unikt du och som ser den sensuella skönheten i en medmänniskas upplevelse och försöker förstå dess semantik. Gränsdragningen mellan vem som hjälper och vem som tar emot hjälp blir diffus, det är i grunden blott två människor som möts. Det är en satsning i inlevelse och närhet som kan hota båda på ett fundamentalt sätt - samma risk som alltid är närvarande då människor möts på ett äkta sätt, vilket den tidigare citerade dikten om osmos visade. Precis som i den dikten är "oss" en enhet som lyfts fram, här typografiskt med extra mellanslag mellan varje bokstav. Laing framhåller att han med "förståelse" inte menar någon rent intellektuell process:

\footnotetext{
I stället kunde man använda ordet kärlek. Men inget ord har blivit mera prostituerat. Det som är nödvändigt - fast inte tillräckligt - är en förmåga att inse hur patienten upplever sig själv och världen, inklusive mig. Kan man inte förstå honom kan man knappast börja "älska" honom så att det leder någon vart. [...] Man kan inte älska ett knippe av "tecken på schizofreni". Ingen "har" schizofreni som man har en förkylning. Patienten har inte "fått" schizofreni; han är schizofren. Man måste lära känna den schizofrena utan att förgöra honom. Han måste upptäcka att detta är möjligt. (Laing 1968: 30-31.)
}

Både hos Laing och Andersson (i dikter och uttalanden som psykiater) finner man tanken att det terapeutiskt verksamma inte handlar om vetenskapliga observationer, diagnostik eller medicinering utan om något så naturligt, och samtidigt så krävande, som kärlek. I dikten "Fenomenologens dilemma" vittnar den långa och alltmer sönderbrutna räckan av existentiella frågor om en fundamental osäkerhet gällande metoden, samtidigt som just icke-vetandet, undrandet och öppenheten framstår som det rätta närmelsesättet. I dikten som tillägnats Kraepelin är all ovisshet eliminerad, där är ordning och reda och inga frågor behöver ställas, även om personalens förvåning kvarstår. Men en sådan psykiatri framstår som verkningslös och djupt oetisk.

I en intervju i Borgåbladet 1975 säger Andersson att han som psykiater inte sitter och analyserar sina patienter utan vill ställa upp på deras egna villkor för att genom dialog arbeta sig till resultat. Han kritiserar "insektforskarinställningen" som medför stämplar och beteckningar som inte håller streck. Motsättningar mellan friska och sjuka, starka och svaga konstrueras och läkarrollen blir ett sätt att utöva makt. (Widén 1975.) En sådan vetenskapssyn sammanfaller i väsentliga avseenden med den som man finner i marxistisk filosofi. Ett gemensamt drag hos marxistiska tänkare som Lukács, Bloch, Korsch och Gramsci är att de var kritiska mot "scientism" (vetenskaptro) och strävade efter att upphäva skrankorna mellan teori och praktik, objekt och subjekt. Det borgerliga tänkandet är enligt Lukács bestämt av det kapitalistiska samhället. Det reifierade, avhumaniserade och atomiserade samhället ger en samhällsvetenskap som bygger på reifierade begrepp och lagbundenheter som övertas från naturvetenskaperna. Detta leder till en rationalitet som behandlar människor som kalkylerbara ting. (Nordin 2007: 27-29.) Även Frankfurtskolan betraktade samhällsvetenskapen, och vetenskap överhuvudtaget, som en del av samhället sjävt. Vetenskapen var med och skapade människors sociala förhållanden. De kritiserade därför posi- 
tivismens tro på en absolut vetenskap som stod utanför den värld den betraktade. (Månsson 2010: I20.)

Andersson gör en insats i den finlandssvenska poesin genom att kritiskt granska psykiatrin; ämnet är nytt och aktuellt. Han är också engagerad under 1960- och 70-talen i olika aktioner mot missbruket av psykiatri i Sovjetunionen, där psykiatrin var "en behändig hjälpreda" för att göra sig av med misshagliga sanningssägare. I Sovjetunionen användes diagnosen "latent schizofreni" för sådan syften. (Andersson 2000: 145.) I Sverige var psykiatriska problem enligt Amelie Björck ännu i början av 1960-talet tabubelagda. Omvärderingen av psykvården hade just startat och en våg av öppenhet - både $\mathrm{i}$ form av patientinflytande och en benägenhet hos gemene man att psykologisera sig själv och visa sitt illabefinnande - skulle bryta igenom först några år senare. Sonja Åkesson var en föregångare när hon skrev inifrån psykinstitutionen och ville visa att mental hälsa och välbefinnande påverkas av yttre faktorer och inte enbart var beroende av individens omedvetna eller av biologiska faktorer. (Björck 2008: 102.) Nämnas kan också Milos Formans kända film One Flew Over the Cukckoo's Nest (1975, Gökboet) med Jack Nicholson i huvudrollen. Den skildrar individens kamp mot mentalsjukhusets slutna system, den enskildes försök att bevara sin frihet i en tvångsinrättning och maktinsitution. Överhuvudtaget är psykiatrin en synlig fråga i offentligheten vid denna tid.

I en dikt ur Genom sprickorna i vårt ansikte beskriver Andersson hur en man börjar må dåligt och hur han ytterligare bryts ner av en oförstående omgivning och en förfelad vård:

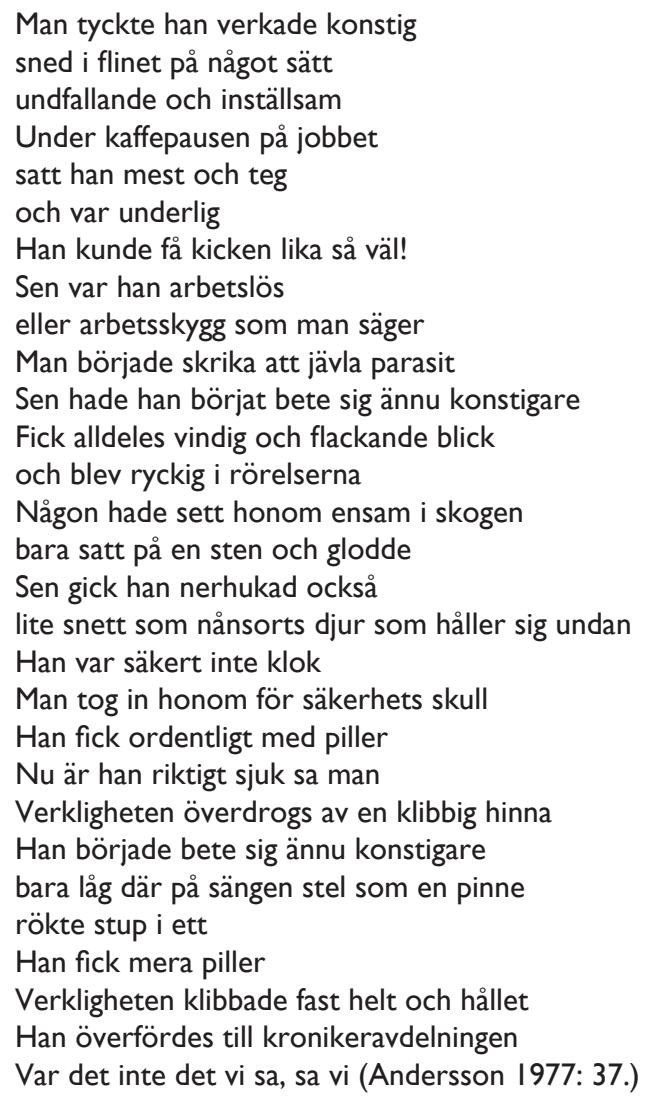


Mannens livsöde förmedlas indirekt av en tämligen likgiltig och tanklös berättare som representerar ett obestämt "vi", "man" och "någon", ett slags allmän mening, folk överlag som känt honom flyktigt. I mannen ser de endast en konstig typ, vars gradvisa nedbrytning framstår som följdriktig och därför föga upprörande. Det oerhörda i hans tragiska levnadslopp förminskas av en avståndstagande hållning, som egentligen upprepar Kraepelins symptominriktade diagnostiska närmelsesätt på ett odifferentierat vis. Samtidigt får perspektivvalet i dikten motsatt effekt: just för att mannens livshistoria berättas så här framstår hans öde som än mer beklagligt.

Andersson förhöll sig kritiskt till den personlighetsnedbrytande och förlamande inverkan som mentalvårdsinstitutionen hade på de intagna. I sitt arbete som psykiater hade han kunnat iaktta hur de intagna på mentalsjukhusens slutna avdelningar småningom blev mera skadade av själva institutionen än av sin primära psykiska sjukdom. Han ger den amerikanske antropologen och sociologen Erving Goffman rätt i hans beskrivning av de totala institutionernas destruktiva inverkan på dem som vistades där. (Andersson 2000: 65-66.) Goffmans kända bok Asylums (Totala institutioner) utkom första gången 1973. Det som utmärker totala institutioner enligt honom är att de bryter ner de gränser som i det moderna samhället vanligen skiljer åt olika livssfärer: det privata, det sociala och det professionella. Alla aspekter av livet utförs på samma plats och under samma auktoritet, varje fas av medlemmens dagliga aktiviteter pågår $\mathrm{i}$ sällskap med andra människor i samma situation, alla faser i de dagliga göromålen är noggrannt planerade. De påtvingade aktiviteterna samordnas i enlighet med en övergripande plan som ska uppfylla institutionens officiella målsättningar. Mänskliga behov hos stora grupper av människor behandlas genom byråkratisk organisation. (Goffman 20II: I4-I5.)

Enligt Goffman har mentalpatientens "moraliska karriär" en retroaktiv karaktär: innan en person anlänt till mentalsjukhuset finns det vanligen inga säkra tecken på att han är förutbestämd för det, men ganska snart framstår situationen så (Goffman 20II: 107). Tvångsintagningen sker för att en person åstadkommit "besvär ute i samhället" och "praktiserat ett för samhället olämpligt uppträdande". Om patienten förkastar institutionens uppfattning om vad och vem han är och protesterar med till exempel vägran att kommunicera tas detta som ett sjukdomssymtom och ytterligare en bekräftelse på att han befinner sig på rätt plats. (Goffman 201 I: 202.) Goffman lyfter fram det relativa i patologibegreppet och menar att diagnostiska avgöranden lätt kan fa en etnocentrisk prägel och bli politiska i den meningen att de uttrycker en viss fraktions intressen (Goffman 20I I: 242-243). Han menar också att mentalsjukvården tillämpar en teknisk servicemodell på sin verksamhet, vilket skapar betingelser som gör att den psykiatriska personalen med nödvändighet misslyckas. Patientens natur omdefinieras så att patienten blir "det slags objekt som psykiatrisk service kan utövas på" samtidigt som tillgången till service är minimal när denne väl gjorts till serviceobjekt. (Goffman 20I I: 254.) 
I dikten ovan innebär intagningen på mentalsjukhus ytterligare en försämring av mannens tillstånd, han medicineras och förlorar det sista av sin initiativförmåga och frihet. Den institution som borde hjälpa innebär hans slutgiltiga fångenskap, i sjukdomen och i systemet. Han blir med Goffmans terminologi ett objekt som det utövas psykiatrisk service på, utan framgång. Mannens allt kraftigare symptombildning uppfattas inte som en adekvat reaktion på missförhållandena $\mathrm{i}$ den totala institutionen utan som en bekräftelse på hans sjukdom. Beskrivningen av sjukdomsförloppet är retroaktiv: tecken på hans kommande öde kunde "man" iaktta redan i arbetslivet, där han var "sned i flinet på något sätt / undfallande och inställsam" - iakttagelserna i sig verkar inte ha något omedelbart samband med mentalsjukdom men vid en tillbakablick kan historien berättas så.

Andersson ansåg att det oformulerade är destruktivt och att sjukdomar är ett slags icke-verbalt språk, kroppens sätt att kommunicera (Andersson 1985: 22I-222; Schön 1975). Samma tanke finns i psykoanalytisk teori: omedvetna konflikter yttrar sig som symptombildningar och genom psykoanalysens medvetandegörande samtalsmetod kan dessa lösas. Det som mannen i dikten kommunicerar icke-verbalt kan ingen i hans omgivning förstå eller svara på, varken i den sociala gemenskapen eller på mentalvårdsinstitutionen, och därför blir han inte frisk utan ännu sjukare och kroppens språk blir alltmer desperat.

Språkets koppling till sjukdom och hälsa är central också i Anna Ovaskas (20II) avhandling pro gradu om författaren Maria Vaaras självbiografiska verk. Ovaska undersöker skrivandets terapeutiska funktion hos Vaara, som skrev sig frisk från sin schizofreni. Även om skrivandet aldrig till fullo kan uttrycka och förmedla de egna psykofysiska erfarenheterna så bildar fantasi, litteratur och skrivande ett öppet psykiskt tillstånd, där jaget kan konstrueras. Ovaska betonar också det konstitutiva i den sjukas relation till andra. Vaaras verk ifrågasätter uppdelningen i friska och sjuka. När Maria framträder som "det andra" hotas enheten även hos övriga individer i omgivningen; hon avlöjar att splittringen gömmer sig under ytan hos oss alla. (Ovaska 20I I: 83-84.) Enligt Ovaska visar Vaaras produktion att jagets mångfald och fragmentariska karaktär inte är en förvillelse utan utgör en etisk grund för relationen mellan jaget och andra. Jaget formas i förhållande till andra och består av alla dessa relationer. Ett skört psyke rubbas lätt när relationerna störs och det enda sättet att återfå meningen i livet är att bygga upp kärleksfulla och tillitsfulla relationer igen. (Ovaska 20I I: 85-86.) Andersson ger uttryck för en liknande syn i sitt efterord till Vaaras debutroman Likaiset legendat (1974, Smutsiga legender):

Psykiatria on luokitellut, tutkinut, diagnostisoinut, säilönyt, lääkinnyt, vedellä ja sähköllä pelotellut ja keksinyt yhä uusia ymmärtämättömyyden ja etäännyttämisen temppuja. Se on toiminut näin, koska se ei ole uskaltautunut osalliseksi siihen kärsimykseen ja koettelemukseen, josta mielen sairaudet ovat turhaan yrittäneet sille kertoa. Psykiatria on ollut kuuro ja - aivan viime aikoihin saakka - myös kielitaidoton. 
Viime vuosikymmenien kuluessa olemme hiljalleen oppineet ymmärtämään, että yhden ihmisen mielen sairaus on ilmaisu monen ihmisen kanssakäymisen ja vuorovaikutuksen vääristymästä. (Andersson [1974] 1975: 274-275. $)^{13}$

I Anderssons dikt om mannen med de psykiatriska problemen är detta kollektiva "vi" och "man" som bedömer honom delaktiga i hans sjukdom. Deras förhållningssätt och allmänna avståndstagande från honom formar en gemensam negativ relation, som för mannen blir ytterst destruktiv och för kollektivet innebär stagnation i en fördomsfull och dumdryg indolens. Den skörare parten reagerar med akuta symptom - ett uttryck för en dålig situation, ett sätt att kommunicera sitt illabefinnande - som småningom definieras som obotlig mentalsjukdom, men den oberörda robustare parten har delansvar för det misslyckade samspelets förödande konsekvenser. Konstaterandena om att "Verkligheten överdrogs av en klibbig hinna" och att "Verkligheten klibbade fast helt och hållet" avviker dock från diktens i övrigt distanserade perspektiv. I dessa omdömen finns ett ögonblicks inlevelse $\mathrm{i}$ den sjukes situation, vilket kan tolkas som kollektivets potential till större förståelse. Här skymtar den fram som en obrukad resurs, men inger också hopp om att något kunde förändras. Inte i denna dikt, men principiellt, i verkligheten. Även avslutningsrepliken "Var det inte det vi sa, sa vi" innebär med sitt ironiska självciterande metaperspektiv ett synvikelskifte som avslöjar att det tidigare anförda subjektet "man" inkluderar "oss". Det vill säga: läsaren kan inte bara tycka att det odefinierade kollektiv som ingår i "man" gäller andra osympatiska och oansvariga personer, utan tvingas se sin egen medverkan i olika grupper och sociala sammanhang. Hur mår människorna omkring dig - i familjen, på arbetsplatsen, i grannskapet? Vilket är ditt ansvar för dem? Blir du själv ett till intet förpliktigande "man" i förhållande till dem eller en enskild individ som tar ansvar för en gemensam relation? Sådana frågor aktualiseras genom dikten.

Mentalsjukdomar i Anderssons poesi, liksom i mycket av samtidens forskning och konst, uppfattas inte som individens enskilda och endogena problem utan som en mellanmänsklig och samhällelig angelägenhet. Anderssons dikter visar på övergrepp som gjorts mot enskilda människor $\mathrm{i}$ vetenskapens och institutionens namn men också på den tanklöshet och bristande solidaritet som vi vanliga medmänniskor gör oss skyldiga till. Att hans samhällsengagerade poesi riktar kritik mot systemet innebär inte att den enskilda (läsaren) befrias från etiska krav. Samhället skapas ju av "oss"; detta solidaritetens pronomen som han i så hög grad skriver om, och för.

\footnotetext{
13 "Psykiatrin har klassificerat, undersökt, diagnosticerat, förvarat, medicinerat, skrämt med vatten och el och har ständigt hittat på nya metoder av oförståelse och distansering. Den har fungerat så, därför att den inte har vågat ta del av det lidande och den prövning som mentalsjukdomarna förgäves har försökt berätta om. Psykiatrin har varit döv och - tills helt nyligen - även okunnig i språk. Under de senaste årtiondena har vi småningom lärt oss förstå att mentalsjukdom hos en människa är ett uttryck för ett förvrängt umgänge och växelverkan mellan många människor.” (Min översättning.)
} 


\section{Avslutning}

\section{KÄLLOR}

\section{Skönlitteratur}

I Finland liksom i den övriga västvärlden var frågor kring individen och samhället aktuella i offentligheten under de politiserade 1960- och 1970-talen och vänstervågens krav på socialt engagemang uttrycktes i demonstrationståg och debatter. Claes Andersson, som aktivt tagit del i samtidens politik, har fört in nya ämnen och grepp i den finlandssvenska lyriktraditionen och som poet nyanserat, problematiserat och belyst aspekter kring motsättningen individ - samhälle. Även om hans dikter är samhällskritiska och knyter an till en ideologisk samtidskontext är de komplexa, inte minst i sin existentiella utblick. I hans dikter är den enskilda människan en produkt av sitt samhälle och en symptombärare som avslöjar när organiseringen av sådant som bostadspolitik och psykiatrisk vård misslyckats.

I min artikel har jag lyft fram Anderssons tidiga politiska poesi för att den är av litteratur- och idéhistoriskt intresse, men också för att den ger perspektiv på dagens samhälle och väcker grundläggande frågor av humanitär karaktär. Den sparsmakade forskningen i hans poesi kom, av någon anledning, av sig på 1980-talet medan läsarna aldrig har övergett honom. Min undersökning av tematiken kring solidaritet, urbanitet och psykiatri kan tyckas bekräfta det "vi alla vet" om Andersson, men faktum är att forskningen i ringa mån visat vad han egentligen säger i sina dikter, hur han gör det och i vilket sammanhang.

Andersson, Claes 1967: Samhället vi dör i. Helsingfors: Schildts.

Andersson, Claes 1969: Det är inte lätt att vara villaägare $i$ dessa tider. Helsingfors: Schildts.

Andersson, Claes 1970: Bli, tillsammans. Helsingfors: Söderströms.

Andersson, Claes 1970: "Dikt till 70-talet". FinskTidskrift 3/I970: I I3-I I 4.

Andersson, Claes 1974: Rumskamrater. Helsingfors: Söderströms.

Andersson, Claes 1977: Genom sprickorna i vårt ansikte. Helsingfors: Söderströms.

Andersson, Claes 1979: Trädens sånger. Helsingfors: Söderströms.

Ferlin, Nils 1985: "Du har tappat ditt ord”. I Lars Gustafsson (red.), Svensk dikt från trollformler till Lars Norén. En antologi sammanställd av docent Lars Gustafsson. Stockholm: Wahlström \& Widstrand.

La Fontaine, Jean de 1959: "Syrsan och myran" [1668]. I urval och översättning av Ivar Harrie, Fabler och noveller. Helsingfors: Söderströms.

Lenngren, Anna Maria 1985: "Epitaf'. I Lars Gustafsson (red.), Svensk dikt från trollformler till Lars Norén. En antologi sammanställd av docent Lars Gustafsson. Stockholm: Wahlström \& Widstrand.

Palm, Göran 1978: "Spegelbilden”. I Tom Hedlund (red.), Den svenska lyriken från Ekelund till Sonnevi. Antologi av Tom Hedlund. 2. uppl. Stockholm: FIBs lyrikklubb/Tidens förlag. 


\section{Sekundärlitteratur}

Saarikoski, Pentti 1969: Katselen Stalinin pään yli ulos. Helsinki: Otava.

Sonnevi, Göran 1985: "Om kriget i Vietnam". I Lars Gustafsson (red.), Svensk dikt från trollformler till Lars Norén. En antologi sammanställd av docent Lars Gustafsson. Stockholm: Wahlström \& Widstrand.

Vreeswijk, Cornelis 1968: "Somliga går med trasiga skor". Urval och koordination Jan Friberg, Cornelis bästa. CD-skiva. 2004 Universal Music AB.

Otryckt

Ovaska, Anna 20I I: Toisia todellisuuksia, murtumia kielessä ja subjektissa mielen sairaus ja kirjoittaminen terapiana Maria Vaaran omaelämäkerrallisessa tuotannossa. Pro gradu-tutkimus, kotimainen kirjallisuus. Helsingin yliopisto: Suomen kielen, suomalais-ugrilaisten ja pohjoismaisten kielten ja kirjallisuuden laitos.

Tryckt

Andersson, Claes 1965: "Men är då diktaren utan del?". FBT I//965: |9-2|.

Andersson, Claes 1975: "Jälkisana”. Maria Vaara, Likaiset legendat, 2. painos s. 273-277. Jyväskylä: Gummerus.

Andersson, Claes 1985: "Sex teser om litteratur och författarskap". Nya Argus 1985, 10/1985: 221-224.

Andersson, Claes 2000: Mina tolv politiska år. Fragment, minnesbilder, drömmar. Stockholm: Albert Bonniers Förlag.

Andersson, Claes 2006: Har du sett öknen blomma? Om skrivandets lust och vånda. Helsingfors: Söderströms Förlag, Lund: Ellerströms Förlag.

Appel, Peter 1979: "Den verklighet vi gärna blundar för" [Intervju med Claes Andersson]. Kyrkpressen 16.8.1979.

Berggren, Camilla \& Lydén, Marianne (red.) 2009: Nyttiga idioter? Unga idealister, Lenin och sjuttiotalet. Helsingfors: Söderströms.

Björck, Amelie 2008: Sonja Åkesson. Stockholm: Natur \& Kultur.

Ekman, Michel 2012: "Mannen som vet att han skall dö. Värld och poetik hos Claes Andersson". Claes Andersson, Hjärtats rum. Valda dikter 1962-2012. Jag älskar dig med mina höstliga dimmor s. 282-297. Helsingfors: Schildts \& Söderströms.

Goffman, Erving 20I I: Totala institutioner. Fyra essäer om anstaltslivets sociala villkor. Översättning Göran Fredriksson. Stockholm: Norstedts Akademiska Förlag.

Grefberg, Tora 1977: "Lyssna, ha tålamod med de ensamma!". [Intervju med Claes Andersson]. Borgåbladet 3.3.1977.

Haapala, Vesa 2007: "Kokeellinen kirjallisuus ja kirjallinen vastarinta Suomessa - kiintopisteenä 1960-luku”. I Sakari Katajamäki \& Harri Veivo (toim.), Kirjallisuuden avantgarde ja kokeellisuus s. 277-304. Helsinki: Gaudeamus. 
Johansson, Ingvar 2007: "Marxistisk filosofi, planekonomi och individualism". I Stefan Arvidsson (red.), Marxismens filosofi. Apropos ett jubileum s. 89-105. Stockholm/Stehag: Brutus Östlings Bokförlag Symposium.

Jonsson, Stefan 1998: "Marxistisk litteraturteori”. I Staffan Bergsten (red.), Litteraturvetenskap - en inledning s. 95-109. Lund: Studentlitteratur.

Kortteinen, Matti 1982: Lähiö. Tutkimus elämäntapojen muutoksesta. Helsinki: Otava.

Laihinen, Arto 197I: "Temaattinen analyysi Claes Anderssinin tuotannosta". Pohjoinen 5/I97I: 31-38.

Laing, Ronald David 1968: Det kluvna jaget. Översättning James Rössel, fackgranskning Magnus Kihlbom. Stockholm: Bokförlaget Aldus/ Bonniers.

Lindgren, Sören 1967: "Claes Anderssons väg". Vasabladet 24.9.1967.

Ljungdal, Arnold 1967: Georg Lukács och marxismens estetik. Stockholm: Albert Bonniers Förlag.

Ljungdal, Arnold 1985: Marxismens världsbild. Stockholm: Norstedts Faktapocket.

Mandelin-Dixon, Mary 1976: "En alkoholist vill inte ha det bra" [Intervju med Claes Andersson]. Astra 9/1976: 8-10.

Meinander, Ragnar 1965: Samhället vi lever i. 6. omarb. uppl. Helsingfors: Söderströms.

Meinander, Ragnar \& Selén, Göran 1978: Samhället vi lever i. Samhällskunskap för gymnasiet. 8. omarb. uppl. Helsingfors: Söderströms.

Månson, Per 2010: "Marxism”. I Per Månsson (red.), Moderna samhällsteorier.Traditioner, riktningar, teoretiker. 8. uppl. Stockholm: Norstedts akademiska förlag.

Nordin, Svante 2007: "Marxismens filosofi". I Stefan Arvidsson (red.), Marxismens filosofi. Apropos ett jubileum s. 13-68. Stockholm/Stehag: Brutus Östlings Bokförlag Symposium.

Rotkirch, Kristina 1967: "Claes Anderssons nya säkerhet”. Nya Argus 12/1967: 175-176.

Rönnholm, Bror 1986: "FBT - tidskrift i tiden”. I Sven Linnér (red.), Från dagdrivare till feminister. Studier i finlandssvensk 1900-talslitteratur s. 257-29I. Helsingfors: Svenska litteratursällskapet i Finland.

Saarikangas, Kirsi 20I0: "Den könsuppdelade förorten”. Översättning Ulla Pedersen Estberg. I Anna Biström, Rita Paqvalen \& Hedvig Rask (red.), Kvinnornas Helsingfors. En kulturhistorisk guide s. 85-9l. Helsingfors: Schildts.

Schön, Lisbeth 1975: "Att tala och skriva motverkar sjukdom”. [Intervju med Claes Andersson]. Ålandstidningen 13.1 I.1975.

Svedjedal, Johan 2014: Ner med allt? Essäer om protestlitteraturen och demokratin, cirka 1965-1975. Stockholm: Wahlström \& Widstrand.

Widén, Gustaf 1975: "Roman och skådespel tar form bakom Villa Biaudets väggar”. [Intervju med Claes Andersson]. Borgåbladet 29.I I.I975. 
Wrede, Johan 1980: "En lyrisk dikt av Claes Andersson". I Torsten Steinby (red.), Historiska och litteraturhistoriska studier 55 s. 269-274. SSLS 487. Helsingfors: Svenska litteratursällskapet i Finland.

Zilliacus, Clas 1972: "Poetik och politik hos Claes Andersson”. Horisont 3/1972: 18-28.

Zilliacus, Clas 1986: "Att dikta är att förändra ljuset”: utvecklingslinjer i Claes Anderssons lyrik". I Ben Hellman \& Clas Zilliacus (red.), Tio finlandssvenska författare s. 149-168. SSLS 535. Helsingfors: Svenska litteratursällskapet i Finland.

[Tidningsartiklarna är från Brages Pressarkiv, Helsingfors]

\section{Författare}

Anna Möller-Sibelius, FD, forskare och timlärare, Åbo Akademi, Litteraturvetenskap

(anna.moller-sibelius[at]abo.fi) 